\title{
PENGARUH KEDALAMAN PENCELUPAN SUDU KINCIR TERHADAP UNJUK KERJA KINCIR AIR
}

\author{
Ignatius Gunawan Widodo ${ }^{1)}$, Alfeus Sunarso' ${ }^{2)}$, Agato $^{2)}$, Halasan Sihombing ${ }^{3)}$, \\ Dominikus Sulistiono ${ }^{3)}$ \\ ${ }^{1)}$ Jurusan Teknik Mesin Politeknik Negeri Semarang \\ JL. Prof. Sudharto, SH Tembalang Semarang, 50275 \\ Telp/Faks: 024 7473417, Fax 0247472396 \\ ${ }^{2)}$ Jurusan Teknik Mesin, ${ }^{3)}$ Jurusan Teknik Elektro \\ Politeknik Negeri Pontianak \\ Email : iggunawan@yahoo.com
}

\begin{abstract}
Abstrak
Penelitian ini bertujuan untuk mendukung pengembangan Pembangkit Listrik Tenaga arus sungai, untuk mendapatkan kedalaman sudu kincir yang paling optimal pada berbagai kecepatan arus sungai. Penelitian ini dilakukan pada skala laboratorium dengan menggunakan peralatan uji unjuk kerja kincir air di Laboratorium Teknik Mesin Politeknik Negeri Pontianak. Peralatan uji unjuk kerja kincir air ini menggunakan saluran eksperimen yang dialiri air dari bak penenang atas, yang diisikan dengan menggunakan dua buah pompa, dimana air dihisap dari bak penampung bawah. Kecepatan air yang melalui saluran eksperimen dapat diatur dengan merubah volume air yang dialirkan, dengan cara menaikan kecepatan pompa air. Penelitian dilakukan dengan mengambil data dari beberapa kecepatan air dalam saluran eksperimen antara lain kecepatan terendah 1,4 m/dt sampai dengan 2,0 m/dt. Data penelitian diperoleh dengan melakukan pengereman sebagai beban pada puli yang berputar dengan pembebanan bervariasi dari $0.2 \mathrm{~kg}$ s/d beban maksimal saat kincir berhenti. Hasil pengujian diperoleh data kecepatan putaran (rpm), beban ( $\mathrm{kg}$ ). Hasil perhitungan dan analisa diolah dalam bentuk grafik antara beban, daya dan efisiensi.Hasilnya menunjukan bahwa semakin dalam pencelupan sudu kincir akan diperoleh daya yang makin besar, sedangkan efisiensinya akan naik juga namun pada kedalaman tertentu efisiensinya akan mengalami penurunan kembali.
\end{abstract}

Kata Kunci : “Kecepatan air”, “kedalaman pencelupan”, “efisiensi kincir air”

\section{Pendahuluan}

Negara kita menghadapai permasalahan energi yang terkait dengan terus menurunnya cadangan bahan bakar fosil (minyak, gas dan batubara) yang merupakan sumber energi utama. Berdasarkan data yang tersedia pada tahun 2004 seperti dilaporkan dalam Blueprint Pengelolaan Energi Nasional 2005-2025, diperkirakan cadangan bahan bakar minyak (BBM) hanya cukup untuk persediaan selama 18 tahun. Selain itu, Indonesia juga menghadapi permasalahan dengan pembangkitan energi listrik yang belum bisa memenuhi kebutuhan masyarakat. Menurut data International Energy Agency (IEA) pemenuhan energi listrik di Indonesia pada tahun 2009 masih di bawah negara tetangga Malaysia, bahkan di bawah Vietnam, Philipina, Srilanka dan Mongolia. Untuk tingkat lokal, data dari PT PLN Wilayah V Kalimantan Barat menunjukkan bahwa rasio elektrifikasi (RE) Kalimantan Barat pada tahun 2010 masih rendah, yaitu 58.32\%.
Permasalahan energi ini mendesak untuk diatasi mengingat peran vital energi dalam menggerakkan berbagai aktivitas di berbagai sektor. Oleh karena itu, di dalam Masterplan Percepatan dan Perluasan Pembangunan Ekonomi Indonesia (MP3EI), bidang energi merupakan salah satu bidang fokus. Untuk Kalimantan Barat, bidang energi ini menjadi sangat penting mengingat bahwa Kalimantan Barat termasuk dalam koridor ekonomi yang akan dijadikan "Pusat Produksi dan Pengolahan Hasil Tambang \& Lumbung Energi Nasional". Untuk mengatasi permasalahan energi di atas, selain diperlukan usaha untuk menghemat pemakaian energi, diperlukan juga usaha untuk memanfaatkan sumber energi baru dan terbarukan. Terkait dengan pemanfaatan energi terbarukan, Kalimantan Barat memiliki potensi sumber daya energi terbarukan yang besar, terutama tenaga arus sungai, karena terdapat banyak sungai yang lebar dengan arus yang deras. 
Tujuan penelitian ini untuk pengembangan prototipe sudu kincir air yang paling efektif pada kondisi jumlah sudu dan berbagai kedalaman pencelupan sudu. Pengujian unjuk kerja kincir air ini dimulai dengan pembuatan beberapa model konseptual dan eksperimental kincir air dan melakukan pengujian unjuk kerja model tersebut terkait dengan perubahan parameter seperti jumlah sudu, bentuk sudu, tinggi celupan, kecepatan aliran, dan torsi beban. Peralatan uji unjuk kerja kincir air ini ditunjukkan pada gambar 1, terdiri dari sistem sirkulasi air dan rangka penopang. Sistem sirkulasi air dilengkapi dengan dua buah pompa dengan kapasitas $90 \mathrm{~m}^{3} /$ jam,putaran maksimum mesin $3600 \mathrm{rpm}$, pipa penghubung diameter 4 inci, bak penenang ( di bagian atas), saluran eksperimen, dan bak penampung (di bagian bawah). Sistem sirkulasi air ini ditopang oleh rangka yang menyangga bak penenang, saluran eksperimen dan pipa penghubung. Rangka penopang saluran eksperimen ini juga menjadi tumpuan bagi lengan pencekam kincir air yang digunakan pada saat eksperimen.

\section{Teori Dasar}

Tenaga air biasa disebut sebagai Hydro Power, hydro power berarti pemanfaatan energi potensial pada air yaitu tekanan, kecepatan, dan kedalaman yang berasal dari aliran air itu sendiri. Energi potensial yang ada pada air bisa digunakan secara mekanis maupun teknis, sebagai pembangkit listrik yang merupakan energi tepat guna. Pemanfaatan energi air dilakukan melalui kincir air maupun turbin air yang memanfaatkan aliran yang berasal dari air terjun maupun aliran air sungai. Salah satu bentuk pemanfaatan tenaga air untuk pembangkit listrik tenaga air adalah kincir air. Kincir air adalah salah satu mesin hidrolis tertua yang kita ketahui dan telah lama dipakai sejak jaman dahulu, dimana menggunakan bahan kayu. Sejalan dengan perkembangan ilmu teknik hidrolis dan teknologi material maka efisiensi kincir air dapat ditingkatkan dengan lebih baik.
Kincir air merupakan sarana untuk mengubah energi air menjadi energi mekanik berupa torsi pada poros kincir.Kincir air diklasifikasikan menjadi beberapa tipe antara lain kincir air undershot, kincir air overshot dan breas shot sebagaimana gambar 1 . Berbagai tipe kincir air di bawah ini.

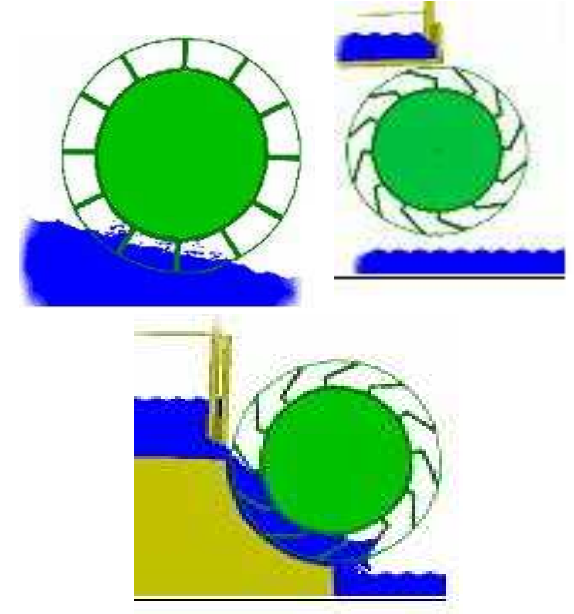

a) Tipe kincir undeshot b) Tipe kincir overshot c) Tipe kincir Breast shot

\section{Gambar 1. Berbagai tipe kincir air}

\section{1) Kincir air undershot}

Tipe kincir undershot bekerja bila air yang mengalir menghantam dinding sudu yang terletak pada bawah kincir tersebut. Tipe ini cocok dipasang pada perairan yang dangkal pada daerah yang rata. Tipe ini sering juga disebut "Vitruvian" dimana aliran air berlawanan dengan arah sudu yang memutar kincir. Keuntungan tipe ini antara lain konstruksinya sederhana, lebih ekonomis, dan mudah dipindahkan, sedangkan kerugiannya antara lain efisiensinya kecil antara 25\%-70\%, dan daya yang dihasilkan relative kecil.

\section{2) Kincir air overshot}

Kincir air overshot bekerja bila air yang mengalir ke dalam bagian sudu sudu sisi bagian atas dan karena gaya berat air roda kincir berputar. Kincir air overshot adalah kincir air yang paling banyak digunakan dibandingkan dengan jenis kincir air yang lain.Keuntungan antara lain tingkat efisiensi 
yang tinggi dapat mencapai $80 \%$, tidak membutuhkan aliran yang deras, konstruksi yang sederhana, mudah dalam perawatan, teknologi yang sederhana mudah diterapkan di daerah yang terisolir.

Sedangkan kerugian kincir air tipe overshot antara lain karena aliran air berasal dari atas maka biasanya reservoir air atau bendungan air memerlukan investasi lebih banyak, tidak dapat untuk mesin putaran tinggi, membutuhkan ruang yang lebih luas untuk penempatan.

\section{3) Kincir air breast shot}

Kincir air breast shot merupakan perpaduan antara tipe overshot dan undershot dilihat dari energy yang diterimanya. Keuntungan kincir tipe breast ini adalah lebih efisiensi dari tipe udershot, dibandingkan tipe overshot tinggi jatuhnya lebih pendek, dapat diaplikasikan pada sumber air aliran rata, sedangkan kerugiannya adalah sudu-sudu dari tipe ini tidak rata seperti tipe undershot (lebih rumit), diperlukan pada arus aliran rata, efisiensi lebih kecil daripada tipe overshot (20\%-75\%).

Pada penelitian ini menggunakan alat uji unjuk kerja kincir air, dimana jenis alat uji unjuk kerja kincir air termasuk pada tipe kincir air undershot, dimana posisi air mengalir melalui saluran eksperimen dan pada saluran eksperimen dipasang kincir air. Air akan mendorong sudu-sudu kincir air dan mengakibatkan sudu -sudu kincir air berputar menghasilkan daya dan putaran. Data diambil berdasarkan kecepatan air pada saluran, kedalaman pencelupan, putaran kincir, dan beban pada puli.

Hasil eksperimen diolah untuk menghitung efisiensi kincir yang merupakan rasio antara daya luaran kincir (daya mekanis) dan daya masukan kincir (daya kinetik aliran). Dari kecepatan aliran $v$, lebar kincir $W_{\mathrm{w}}(10 \mathrm{~cm})$, dan kedalaman celupan kincir $D_{\mathrm{w}}$, masukan kincir dapat dihitung dengan persamaan:

$$
P_{\text {in }}=\frac{1}{2} \rho W_{\mathrm{w}} D_{\mathrm{w}} v^{3}
$$

Sementara dari gaya pengereman $F_{\mathrm{B}}$ dan kecepatan putar kincir $n$ (dalam rpm), daya luaran kincir dapat dihitung dengan persamaan:

$$
P_{\text {out }}=\frac{\pi n r F_{\mathrm{B}}}{30}
$$

Dengan demikian, efisiensi kincir $\eta$ dapat dihitung dengan persamaan:

$\eta=\frac{P_{\text {out }}}{P_{\text {in }}}=\frac{\pi n r F_{\mathrm{B}}}{15 \rho W_{\mathrm{w}} D_{\mathrm{w}} v^{3}}$

Di sini $\rho$ adalah masa jenis air $\left(998 \mathrm{~kg} / \mathrm{m}^{3}\right)$

dan $r$ adalah jari-jari puli rem $(7 \mathrm{~cm})$.

\section{Metodologi}

Tujuan penelitian ini untuk pengembangan prototipe sudu kincir air yang paling efektif pada kondisi jumlah sudu dan berbagai kedalaman pencelupan sudu. Pengujian unjuk kerja kincir air ini dimulai dengan pembuatan beberapa model konseptual dan eksperimental kincir air dan melakukan pengujian unjuk kerja model tersebut terkait dengan perubahan parameter seperti jumlah sudu, bentuk sudu, tinggi celupan, kecepatan aliran, dan torsi beban. Peralatan uji unjuk kerja kincir air ini ditunjukkan pada gambar 2. Peralatan laboratorium unjuk kerja kincir air, terdiri dari sistem sirkulasi air dan rangka penopang. Sistem sirkulasi air dilengkapi dengan dua buah pompa dengan kapasitas $90 \mathrm{~m}^{3} / \mathrm{jam}$, putaran maksimum mesin 3600 rpm, pipa penghubung diameter 4 inci, bak penenang ( di bagian atas), saluran eksperimen, dan bak penampung (di bagian bawah). Sistem sirkulasi air ini ditopang oleh rangka yang menyangga bak penenang, saluran eksperimen dan pipa penghubung. Rangka penopang saluran eksperimen ini juga menjadi tumpuan bagi lengan pencekam kincir air yang digunakan pada saat eksperimen. 


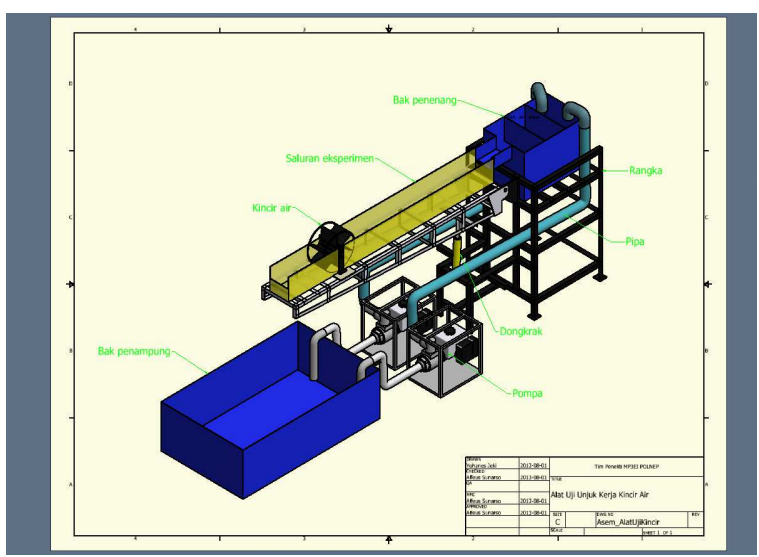

Gambar 2. Peralatan laboratorium Uji unjuk kerja kincir air

Pada saat peralatan uji unjuk kerja kincir air ini dioperasi, air dari bak penampung dihisap oleh pompa dan dialirkan ke bak penenang di bagian atas, kemudian diteruskan ke saluran eksperimen dan kembali ke bak penampungan di bagian bawah, sehingga membentuk suatu siklus tertutup. Kecepatan dan tinggi rendaman air di dalam saluran eksperimen dapat diatur dengan mengatur kemiringan saluran eksperimen menggunakan dongkrak hidrolik, maupun dengan mengatur kecepatan putar pompa sirkulasi yang berpengaruh pada debit air yang dipompakan. Tinggi celupan kincir di dalam air diatur dengan mengatur kemiringan relatif lengan pencekam yang akan mengubah posisi relatif sumbu kincir terhadap permukaan air.

Metode pengujian unjuk kerja model kincir dengan sudu lurus variabel jumlah sudu 8 buah dan 12 buah, dimana variabel kecepatan pada tabel 1 .

Tabel 1. Kondisi eksperimen variabel kecepatan aliran terhadap unjuk kerja kincir

\begin{tabular}{crrr}
\hline $\begin{array}{c}\text { No. } \\
\text { Eksperimen }\end{array}$ & $\begin{array}{c}\text { Kecepatan } \\
\text { Aliran [m/s] }\end{array}$ & $\begin{array}{c}\text { Kedalaman } \\
\text { Aliran [cm] }\end{array}$ & $\begin{array}{c}\text { Kedalaman } \\
\text { Celupan } \\
\text { Kincir [cm] }\end{array}$ \\
\hline 1 & 1.40 & 3.0 & 2.5 \\
2 & 1.48 & 3.5 & 3.0 \\
3 & 1.65 & 4.0 & 3.5 \\
4 & 1.98 & 6.0 & 5.5 \\
\hline
\end{tabular}

Sedangkan kondisi eksperimen untuk mempelajari pengaruh kedalaman celupan terhadap unjuk kerja kincir dengan variabel sebagaimana pada tabel 2 .

Tabel 2. Kondisi eksperimen variabel pengaruh kedalaman celupan

\begin{tabular}{crrr}
\hline $\begin{array}{c}\text { No. } \\
\text { Eksperimen }\end{array}$ & $\begin{array}{c}\text { Kecepatan } \\
\text { Aliran [m/s] }\end{array}$ & $\begin{array}{c}\text { Kedalaman } \\
\text { Aliran [cm] }\end{array}$ & $\begin{array}{c}\text { Kedalaman } \\
\text { Celupan } \\
\text { Kincir [cm] }\end{array}$ \\
\hline 1 & 1.98 & 6.0 & 5.5 \\
2 & 1.98 & 6.0 & 4.0 \\
3 & 1.98 & 6.0 & 3.0 \\
\hline
\end{tabular}

\section{Hasil Dan Pembahasan}

Hasil eksperimen pada berbagai kecepatan aliran diperlihatkan dalam bentuk grafik hubungan antara daya terhadap gaya pengereman (beban) pada berbagai kecepatan, ditunjukan pada gambar 3(a) dan 3(b), disimpulkan bahwa dengan meningkatnya kecepatan aliran, maka daya yang dihasilkan kincir meningkat. Peningkatan daya yang dihasilkan kincir ini terkait dengan peningkatan daya masukkan kincir. Di lain pihak, efisiensi kincir cenderung menurun jika kecepatan aliran meningkat. Penurunan efisiensi ini terkait dengan meningkatnya turbulensi (olakan) akibat tumbukan aliran air dengan kincir. Sedangkan pada garafik hubungan antara daya terhadap gaya pengereman (beban) pada berbagai kedalaman pencelupan dan grafik hubungan efisiensi terhadap gaya pengereman pada berbagai kedalaman pencelupan yang ditunjukan pada gambar 4 (a) dan (b) disimpulkan bahwa perubahan unjuk kerja kincir akibat perubahan kedalaman pencelupan kincir ini memiliki kecenderungan yang serupa dengan akibat perubahan kecepatan. Dengan meningkatnya kedalaman pencelupan, daya yang dihasilkan kincir akan meningkat, tetapi pada kondisi tertentu efisiensi kincir air akan menurun kembali. Dari hasil eksperimen secara keseluruhan, tampak bahwa efisiensi maksimum model kincir air dengan sudu lurus mencapai range antara $25 \%$ sampai dengan $30 \%$. 


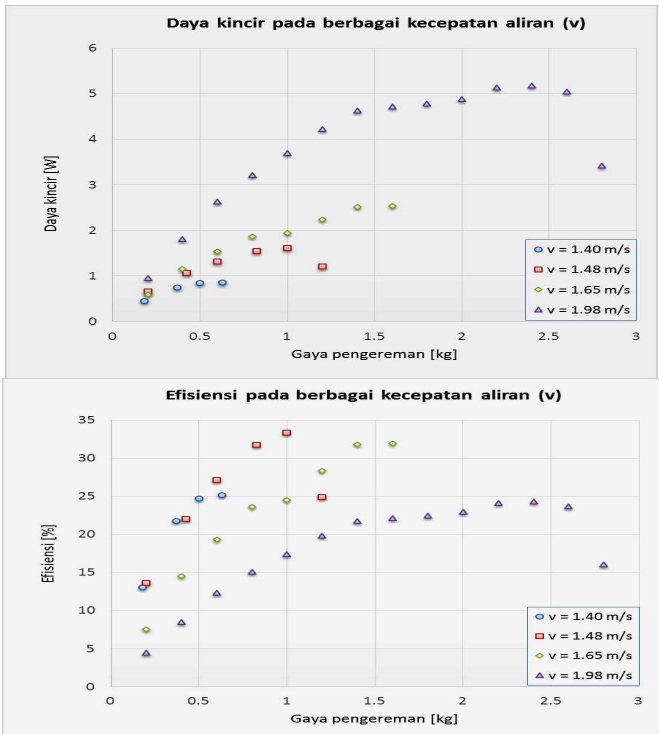

a) Grafik hubungan daya dan beban

b) b) Grafik hubungan gaya dan efisiensi

Gambar 3. Hasil pengujian gaya pengereman (beban) terhadap kecepatan dan efisiensi

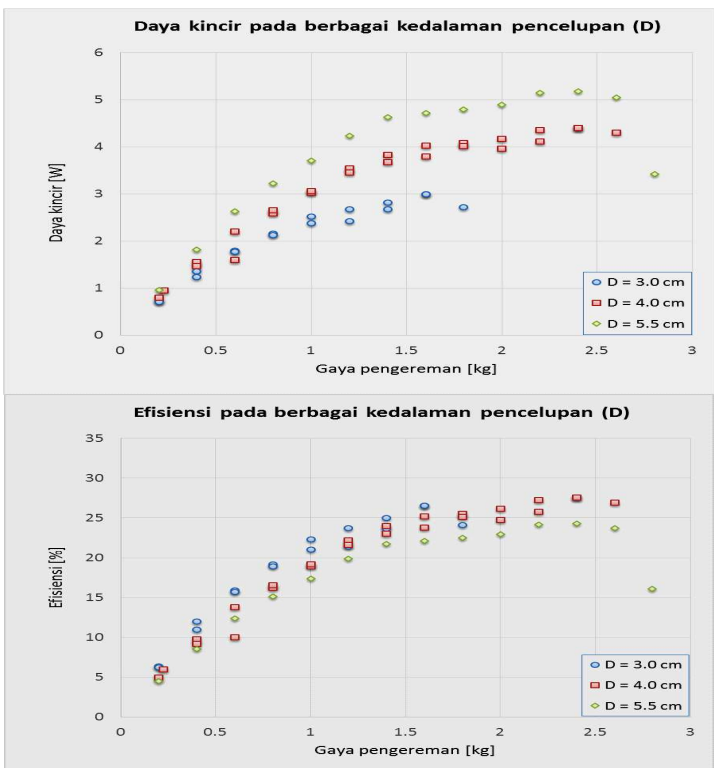

Gambar 4. Hasil pengujian gaya pengereman (beban) terhadap kedalaman pencelupan dan efisiensi.

\section{Kesimpulan}

Hasil eksperimen pada berbagai kecepatan aliran disimpulkan bahwa perubahan unjuk kerja kincir akibat perubahan kedalaman pencelupan kincir ini memiliki kecenderungan yang serupa dengan akibat perubahan kecepatan. Dengan meningkatnya kedalaman pencelupan, daya yang dihasilkan kincir akan meningkat, tetapi pada kondisi tertentu efisiensi kincir air akan menurun kembali.

\section{Ucapan Terima Kasih}

Ucapan terima kasih kepada pengelola program dikti MP3EI, pemerintah daerah Kabupaten Bengkayang dan kabupaten Sekadau yang telah mendanai penelitian ini, sehingga dapat terlaksana kegiatan pendukung penelitian MP3EI untuk membuat desain prototipe pembangkit listrik tenaga arus sungai (PLTAS) di desa Mensibu Kab. Bengkayang dan Desa Manjang Kabupaten Sekadau.

\section{Daftar Pustaka}

- Anagnostopoulos J.S and Papantonis D.E.,2007, Flow Modeling and Runner Desaign Optimization in Turgo Water Turbines, World Academy of science, Engineering and Technology 28

- Anurat Tevata and Chainaring Inprasit, 2011, The effect of Paddle Number and Immersed Radius Ratio on Water Wheel Performance, Faculty of Engineering University of Technology Lanna tak, Thailand.

- Muhammad As'ad Abidin, Rudy Soenoko, Djoko Sutikno, Pengaruh besar sudut kelengkungan sudu terhadap unjuk kerja kincir air Tipe sudu lengkung overshut, Jurusan Teknik Mesin Universitas Brawijaya Malang

- Sunarso dkk, 2013, Laporan akhir Penelitian Prioritas Nasional Masterplan Percepatan dan Perluasan Pembangunan Ekonomi Indonesia (MP3EI), Pengembangan Pembangkit Listrik Tenaga Arus Sungai untuk mendukung Percepatan dan Perluasan Pembangunan Ekonomi di Kalimantan Barat, Politeknik Negeri Pontianak, Pontianak. 